\title{
人為影響により潟口部が常時開ロしたスリ ランカ南部の潟湖における塩分成層 FIELD INVESTIGATIONS ON SALINITY STRATIFICATION OF COASTAL LAGOON WITH PERMANETLY OPENED MOUTH IN SRI LANKA
}

\author{
古里 栄一 ${ }^{1}$ ・田中 規夫 ${ }^{2,3} \cdot$ G. P. Amarasekara ${ }^{4}$, T. Priyadarshana ${ }^{4}$ \\ Eiichi FURUSATO, Norio TANAKA, G. P. Amarasekara, T. Priyadarshana \\ 1正会員 博 (工) 埼玉大学大学院助教 理工学研究科(干338-8570 さいたま市桜区下大久保255) \\ 2正会員 工博 埼玉大学大学院教授 理工学研究科(同上) \\ 3 正会員 工博 埼玉大学総合研究機構教授 環境科学研究センター (同上) \\ ${ }^{4}$ Faculty of Fisheries and Marine Sciences \& Technology, University of Ruhuna
}

Field investigations were conducted on 22 November 2011during rainy season and 16 March 2012 during dry season to estimate the present state of density stratification of Koggala Lagoon, Sri Lanka. The variation of salinity, water temperature and dissolved oxygen were measured vertically at the neap tide condition. Koggala lagoon exhibits an entirely different mixing state depending on the season. In rainy season, lagoon water was brackish and in weak mixing state. On the other hand, in dry season, water in both the lagoon mouth and inside the lagoon exhibit the state of strong mixing and high salinity. In both seasons, high temperature, high salinity and, low dissolved oxygen at the deep layer of water were found in the central part of the lagoon. The salinity level at the bottom was higher than the estimated level based on water budget analysis.

Key Words : Koggala lagoon, rainfall, stream stratification, high salinity bottom layer

\section{1. はじめに}

スリランカでは近年経済発展に伴い活発な社会資本整 備が行われており，潟湖環境が激変しつつある1), 2), 3). コッガラ潟湖はスリランカ全体で計43存在する沿岸潟湖 の1つであり, 南部主要都市のゴールから約 $10 \mathrm{~km}$ 東に位 置する. 本潟湖では河口砂州の除去や突堤建設によって 沿岸漂砂動態の変化が近年生じ, 潟口が常時開口するよ うになった，その結果，潟湖塩分が上昇し，淡水性の種 が多かった潟湖内の動植物の多くが確認できなくなった。 同時に流域水田の塩化や潟湖での漁獲量の減少が生じ, 潟湖の生態系だけでなく自然資源に依存した地域経済に 深刻な影響を与えている1).

これまでに埼玉大学とルフナ大学との共同研究として コッガラ潟湖の水文特性の研究が実施されてきた ${ }^{4), 5), 6) . ~}$

潟口形状の適切な改良により塩水浸入量や交換率等が近 年の潟口開口以前の状態に近づく可能性があることが明 らかになっている4). 今後のコッガラ潟湖の水環境をよ り適切に修復・管理する上では，水文特性に加えて潟湖 開口後の水理・生態系の現状に関する更なる総合的理解
が必要である。

潟湖の水環境は沿岸域の生態系を構成する諸生物の八 ビタットとして，生活史の一部あるいは全てを構成する 重要な場であるとともに，漁獲・観光資源を育むなど社 会経済的な価值も有している. 潟湖において生じる様々 な水理現象の1つに塩分成層がある. 潟湖の塩分や混合 度は潟湖に応じて異なるだけでなく，同一潟湖において も潮汐や淡水流入量に応じて変動する. 潟湖の生態系は こうした時空間的に微妙なバランスの汽水環境を基盤と して成立しており，塩分成層は塩分と並んで潟湖の水環 境に対する人為的圧力を評価する上で重要な要素の一つ である. しかも塩分成層は密度流が支配的となる汽水域 における流れを規定する要素でもある。すなわち，水文 学的特性や密度流現象と生態学的過程は塩分成層特性を 通じて関連している. 今後のコッガラ潟湖の望ましいあ り方を検討するためには，既往研究における水収支バラ ンスに基づく塩分に関する議論 ${ }^{7}$ を発展させる上で成層 状態の実態把握は急務である. なお，本研究は潟口の開 口状態と潟湖成層状態との関係に着目しているが，これ を十分に評価できる開口前のデータが存在しないことか 


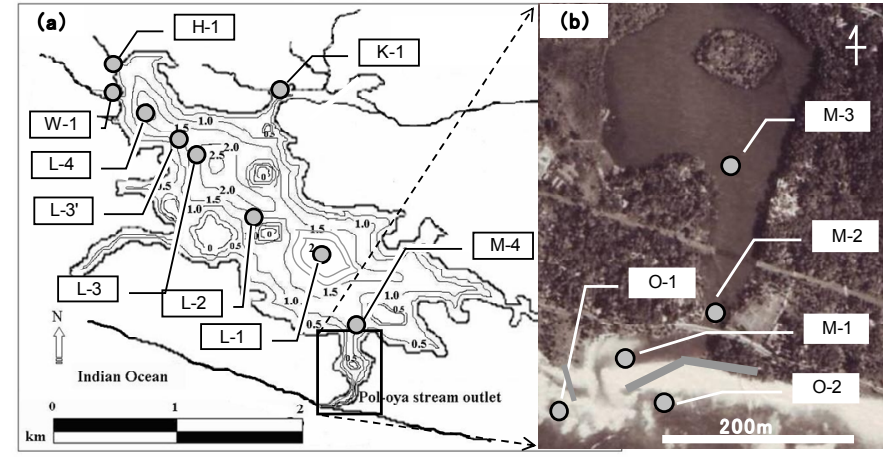

図-1 コッガラ潟湖の形状および現地調査地点（図中記号, 地点名） （a) 全域 コンター線は0.5m毎の水深を示す. (b) 潟口拡大写 真（1985年スリランカ沿岸保全省） グレ一線は突堤を示す.

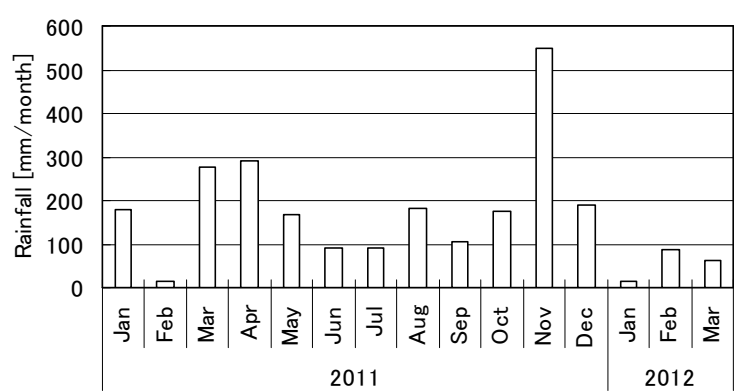

図-2 コッガラ潟湖近傍の雨量（ゴール観測所）

ら，こうした研究の端緒として現状の成層状態の実態把 握を主たる目的としたものである. また，今後の数值解 析等による開口と成層の関係評価に資するものである.

本報はコッガラ潟湖の塩分成層の実態および特性につ いて現地調査を実施して検討するとともに，本潟湖の修 復方策を検討するために必要な課題抽出を目的としたも のである.

\section{2. コッガラ潟湖における潟口部の地形変化}

図-1 (b) に潟口の常時開口前の衛星写真を示す. 開口 前の1985年には，東から西方向への沿岸漂砂が形成した 砂州によって潟口閉塞が生じている．写真には周辺流域 の浸水防止のための掘削により幅 $10 \mathrm{~m}$ 程度の開口部が形 成されている様子も確認できる. こうした潟口閉塞は年 間約7〜8ケ月間生じていた ${ }^{1)}$. 近年，潟口部の砂州除去 （1992年）によって生じた国道橋の橋脚部の侵食抑制の ために潟口外部での突堤建設（1997年および2005年）が 実施された。その後，以前は雨季の開口時のみに幅 $55 \mathrm{~m}$, 水深 $0.5 \mathrm{~m}$ の断面形状であった潟口は，常時開口状態とな り断面も幅 $85 \mathrm{~m}$, 水深 $3 \mathrm{~m}$ 一と拡大した7)。これは従前は 砂州を形成しつつ動的平衡状態であった東方からの沿岸 漂砂動態が突堤により変化して, 砂州が形成されなく なったためである1).

\section{3. 調査方法}

図-1にコッガラ潟湖の形状や位置および調査地点を 示す. コッガラ潟湖の流域面積は約55 $\mathrm{km}^{2}$ であり，こ のうち約 $15 \%$ を潟湖が占めている1). 潟湖の水深は, 1.0 から $3.7 \mathrm{~m}$ であり ${ }^{8)}$ ，淡水は潟湖北西部の4つの小河 川から流入する(図-1). 潟湖の南東に位置するPol-oya は唯一の流出河川であり, 約 $300 \mathrm{~m}$ の水路を通じてイ ンド洋と接続する. 現地調査地点は, 淡水および塩水 の潟湖へ影響を考慮して主たる流入河川としての3地点 (W-1, H-1, K-1)および潟湖内地点として縦断的な数地点 (L-1, 2, 3, 3’)とした. 流入河川においては, 各河川に設 置されている小規模堰の下流部で調查を行った. 潟口 部は侵入する海水の混合や潮汐の影響により複雑な現 象が生じると想定されることから約 $300 \mathrm{~m} の$ 潟口水路長 範囲に4地点設定した(M-1，2，3，4)(図-1). なお，浸入す る海水の塩分濃度の評価のために海域でも2地点で調査 を行った $(\mathrm{O}-1,2)$.

図-2に，コッガラ潟湖から西方向約 $10 \mathrm{~km}$ に位置する ゴール観測所の降雨量を示す．スリランカには5月から9 月の南西モンスーンと 10 月から 2 月の北東モンスーンが 存在する、ゴールでは5月および10月をピークとして年2 回の雨季がある. この降雨特性を踏まえ，2011年11月22 日 (雨季) および2012年3月16日 (乾季) の午前10時か ら午後5時まで潟口から上流水域方向に現地調査を実施 した（以後雨季調査，乾季調査とする）。 なお，潟口開 口以前においては，11月は最低塩分が，3月は最高塩分 が観測された時期である. . 潮汐条件は，塩水の残存に よる潟湖の成層の有無を評価することを念頭に置き，両 日ともに小潮期の下げ潮時に実施した。 なお両調査の前 日まで潟湖周辺では降雨がみられた。

現地測定は多項目水質測定装置(YSI Model 55)を用い

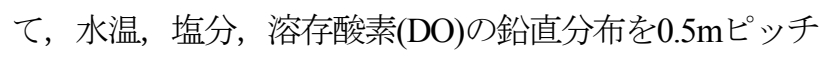
で測定した。

\section{4. 調査結果}

\section{(1) 雨季調査}

図-3に2011年11月に雨季調査として実施した調査結果 を示す．潟口エリア(図-3上)においては，上流側に向っ て塩分の低下(10から20pptの範囲)に加えて，混合度が弱 くなる傾向があった．水温およびDOの鉛直分布も塩分 と同様の傾向であった，M-4地点においては底層に低 DO高水温層が確認されたことから，本水塊は一定時間 混合せずに底層に停滞していたと推定される.

潟湖内部の測定結果を，比較のため潟口水域の上流地 点(M-4) と主たる流入河川地点 (W-1) とあわせて示した

（図-3下）。各項目の鉛直分布および測定值は全調査地 点において類似した傾向を示した. 表層塩分は約 $10 \mathrm{ppt}$ であり，水深約 $1 \mathrm{~m}$ 付近に形成された塩分躍層付近では， 水温およびDOの双方とも躍層が形成されていた. 注目 されるのが, 最深部水域(L-1)において確認された高水温 

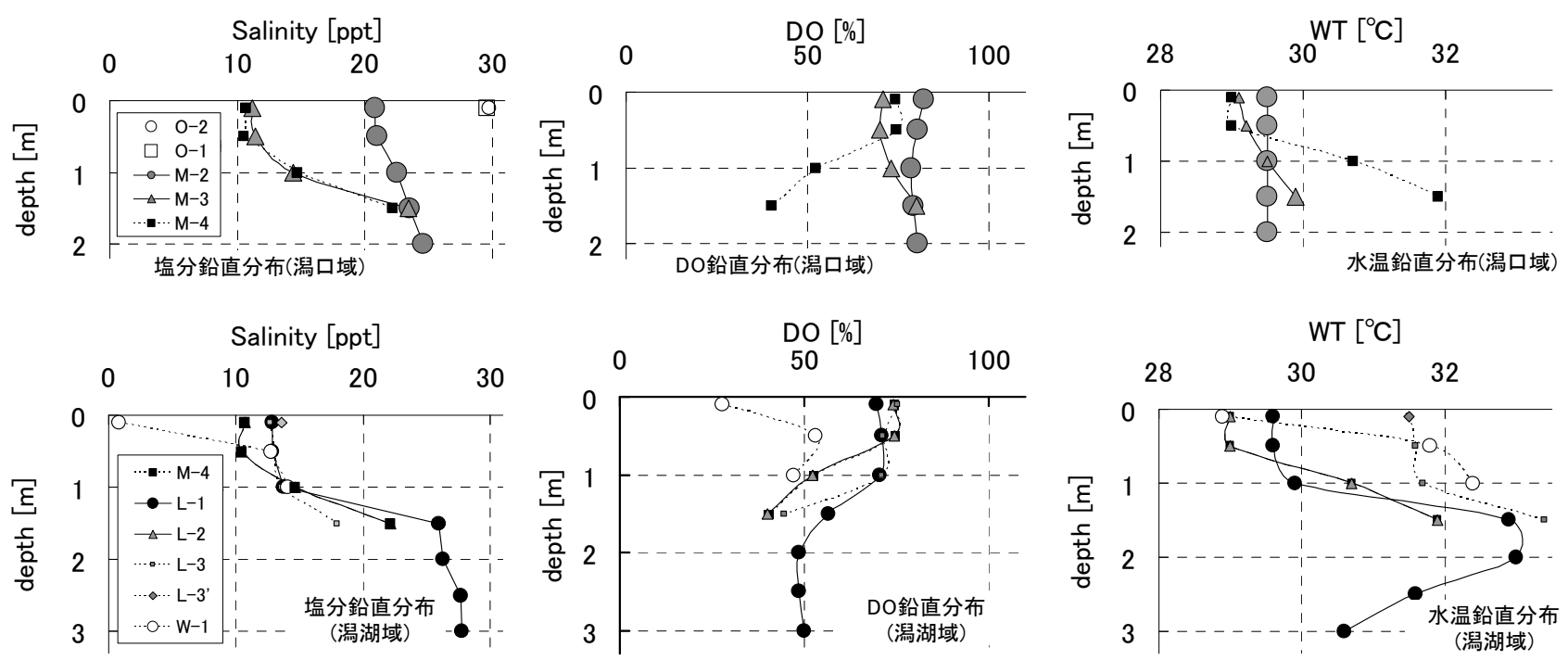

図-3 雨季(2011年11月22日)における潟口 (上)および潟湖内部水域(下)の鉛直分布測定結果（凡例は調査地点名を示す(図1参照)）.

低DO濃度の底層水塊である，これは，水温上昇とDO低 下の生じる一定時間，底層と表層とが混合していないこ とを示している．なお，他の流入河川はW1地点とほぼ 同様な傾向であったために掲載は省略する.

\section{(2) 乾季調査}

図-4に2012年3月16日に乾季調査として実施した各地 点の調査結果を示す.

潟口エリアでは下げ潮期間においては，全測定項目の 值は鉛直および流程方向に均一であった。したがって本 調査時期における潟口水域は，強混合状態であったと推 定される.

潟湖内地点における各測定項目の鉛直分布測定結果を, 比較のために潟口水域の最上流端地点(M-4) と代表的な 流入河川地点(W-1) とあわせて示す。塩分の鉛直分布は 各地点において同様であり，約30 pptであった。ただし 潟湖中央部の最深部 (L-1)においてのみ, 水深 $2 \mathrm{~m}$ 以深の 底層に数ppt高い塩分が観測された。この底層は表層に 比べ低DO高水温であった。 したがって，乾季において も雨季と同様に一定期間底部の水塊は表層と混合するこ となく滞留していると推定される.

流入河川においては，雨季調査結果と同様に塩分およ び水温成層が全3地点で確認された(図-4下). ただし塩分 レベルは各河川において異なっていた.

\section{(3) 降雨量の異なる時期の表層塩分空間分布}

図-5に表層塩分の縦断分布を雨季および乾季で比較し て示す．先述したように，乾季におけるコッガラ潟湖の 塩分は海水と同レベルであり，流入河川表層でのみ 10ppt以下の低い塩分が観測された. これに対して雨季 は全く異なった縦断分布傾向であり，潟口水域は $300 \mathrm{~m}$ 長の潟口水路部で約30pptから10ppt 一減少し，潟湖内表 層塩分は10pp強であり顕著な縦断分布は見られない. し たがって，潟湖水域は雨季乾季に関わらず流れ方向の塩 分勾配はほぼ存在していなかった。なお，これらは共に 小潮での傾向であることから，潮汐の影響が大きくなる
大潮時期においては，雨季において海水の影響が更に強 くなる可能性がある.

\section{（4）現在のコッガラ潟湖の塩分成層}

以上の現地調査結果および考察に基づき，現在のコッ ガラ潟湖の塩分成層の実態に加えて, これを生じている と推定される水理学的諸過程について雨季および乾季別 に概念図で示した（図-6）。現在のコッガラ潟湖は，降 雨量の違いに応じて塩分および混合状態の空間分布は全 く異なった傾向がある．雨季における潟湖は緩混合であ り塩分は汽水レベルであった。潟口域は塩分濃度が下流 ほど高くなるとともに，混合状態も緩混合から強混合 と変化する．なお，潟湖最深部では底層水が一定時間滞 留していると推測された (図-6(a)). 各流入河川では表 層の淡水と下層の汽水から形成される塩分成層が確認さ れた．表層淡水は降雨に由来すると考えるのが妥当であ ろう。一方，汽水については潟湖内と同レベルの塩分で あったことから密度流として潟湖から遡上した水塊で あったことが考えられる.この場合，コッガラ潟湖は， 潟口水域だけでなくラグーン流入河川の双方に緩混合域 が存在していることになる.ただし, 現在は流域の水田 が塩化していることに加えて耐塩性の弱い種のマング ローブが流域で減少している1)ことを考えると，既に流 域からの基底流出分が汽水化している可能性もあり，流 入河川部の汽水動態については今後の研究課題である. いずれにしろ，流入河川の表層淡水レベルは潟湖上流部 水域のL-3地点でも測定されなかったことから，表層密 度流として潟湖に流入した淡水塊は潟湖内で風灾力等に より潟湖汽水と混合していると考えられる.

一方，乾季における潟湖の塩分空間分布は雨季と全く 異なった様相を示した(図-6（b））．潟湖全域において塩 分は海水レベルであり混合形態は強混合であった．現 在のコッガラ潟湖は，乾季においては潟湖ではなく湾に 類似した状況となっている. 流入河川は雨季と同様に塩 分成層が生じていた。しかしながら雨季とは異なり，下 

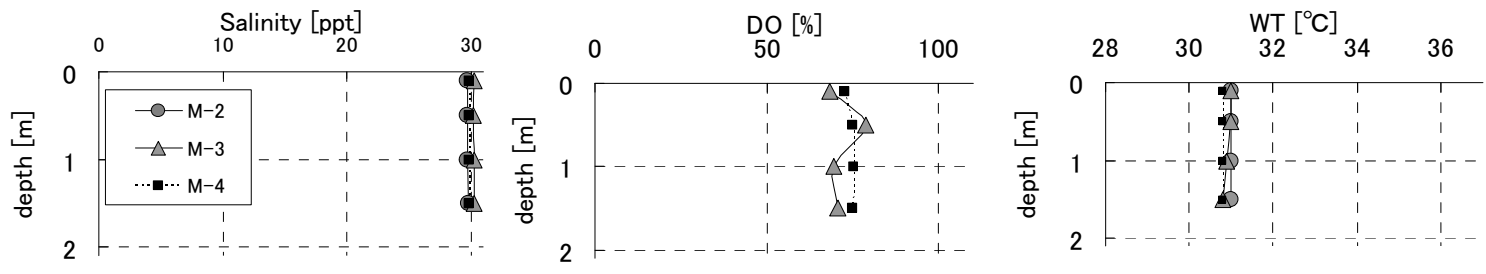

塩分鉛直分布(潟口域)

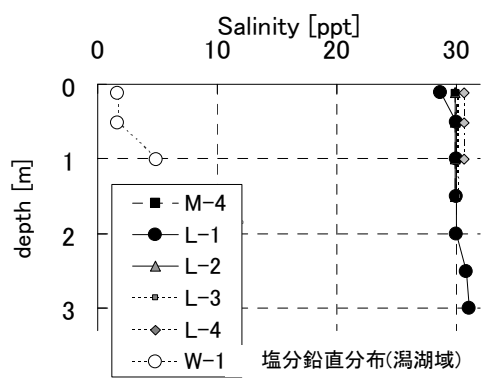

DO鉛直分布(潟口域)

DO [\%]
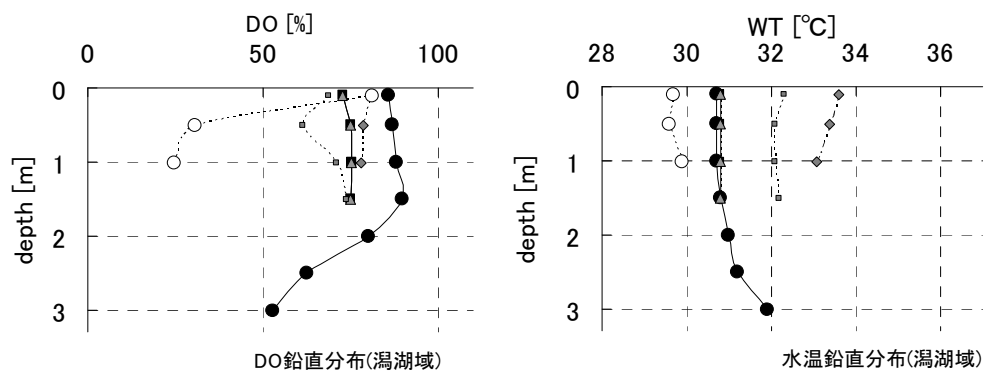

DO [\%]
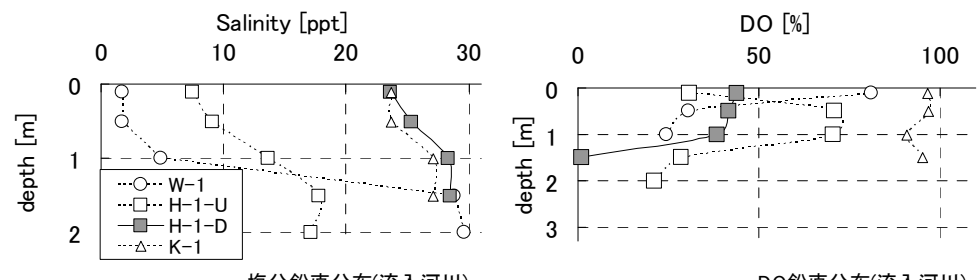

WT $\left[{ }^{\circ} \mathrm{C}\right]$

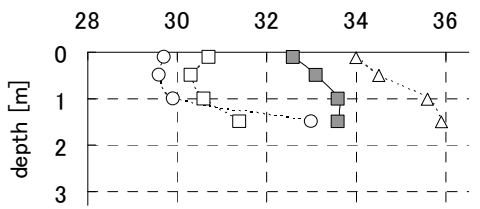

DO鉛直分布(流入河川)

水温鉛直分布(流入河川)

図-4 乾季(2012年3月16日)における潟口(上), 潟湖内 (中)および流入河川(下) 水域の測定結果(マ一カ一は各測定地点 を示す (図1))

層汽水の塩分濃度が河川によって異なっていたことに加 えて, これらは潟湖の塩分よりも明らかに低かった(図一 4下). この下層汽水の起源については雨季と同様に流域 および潟湖内部からの遡上水の双方の可能性がある。こ れは現在のコッガラ潟湖の水収支および塩分動態の評価 における課題である.

Gunaratne ら ${ }^{4), 7}$ は水収支の推定結果に基づいてコッガ ラ潟湖の塩分に流入河川水量の季節変化が強い影響を与 えていることを指摘した．本調査結果は，こうした季節 変化が塩分だけでなく混合状態に対しても強い影響を与 えていることを示している.

本調查は流入河川水量の影響が相対的に大きい小潮時 を対象に実施した。逆に潮汐の影響が大きくなる大潮時 であれば，雨季の塩分空間分布は本調査結果とは異なる 傾向が生じる可能性がある．たとえば図-5に示した縦断 方向の塩分分布は，大潮時は陸方向に高い塩分の範囲が 広がると推測される，なお，雨季および乾季両調查にお いて最深部で観測された高塩分水の起源としては, 調查 実施前の大潮時に流入した海水が一定期間以上残存した と考えるのが妥当である.これは，この下層水の水温が 表層以上であること, 調査時の本地点の透明度が $1.2 \mathrm{~m}$ で あったことからからも裏付けられる. ただし，この現象 が生じるためには，大潮時の遡上海水が高い塩分を維持 しながら潟口部を通過して潟湖最深部に到達寸る必要が ある. 小潮時に実施した本調査ではそうした高密度水の 貫入状況は確認されなかった．今後明らかにすべき重要 な課題の一つである. なお，乾季は流入淡水量が少ない

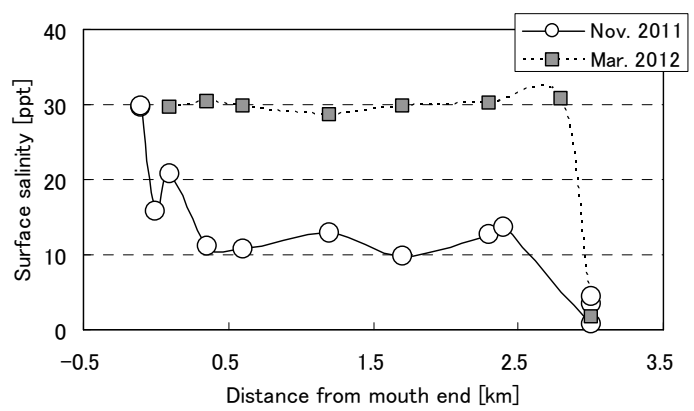

図-5 表層塩分の流程方向の変化

ために小潮条件と同様な塩分の空間分布が大潮条件にお いても生じると推測される.

\section{5. 考察}

\section{（1）潟口部の閉塞特性の変化による水環境への影響}

Gunaratne $^{7}$ は，コッガラ潟湖の潟口開口前後における 塩分の変化に関して, 水収支の推定結果に基づいた様々 な水文学的なパラメーターによる評価を行っている. 開 口により潟口断面積が約10倍に増加したことに加えて年 間約8ヶ月間閉塞していた潟口が常時開口したことによ り, 満干時の潮位差にもとづく潟湖容積に相当するタイ ダルプリズムは $0.7 \times 10^{6} \mathrm{~m}^{3}$ から $1.7 \times 10^{6} \mathrm{~m}^{3}$ に約 2.4 倍に増 加した. $9.4 \times 10^{6}\left[\mathrm{~m}^{3}\right]$ の潟湖容積および約 $8 \mathrm{~m}^{3} / \mathrm{s}$ の総淡水 流量の推定值を用いて, 開口の影響について, 潟湖容積 や陸域からの流入量とのバランスから評価するとともに, 潟湖平均塩分が9から $24 \mathrm{ppt}$ に増加したことを説明した。 こうした既往研究により現在および過去のコッガラ潟湖 


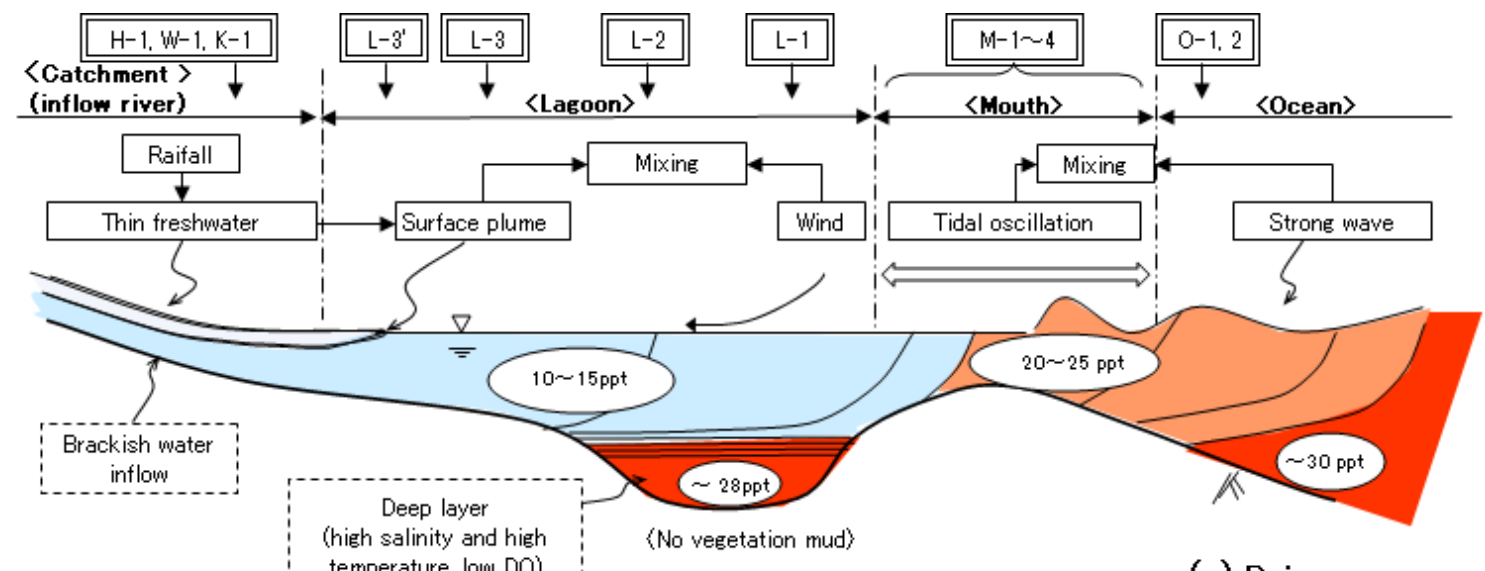

(a) Rainy season

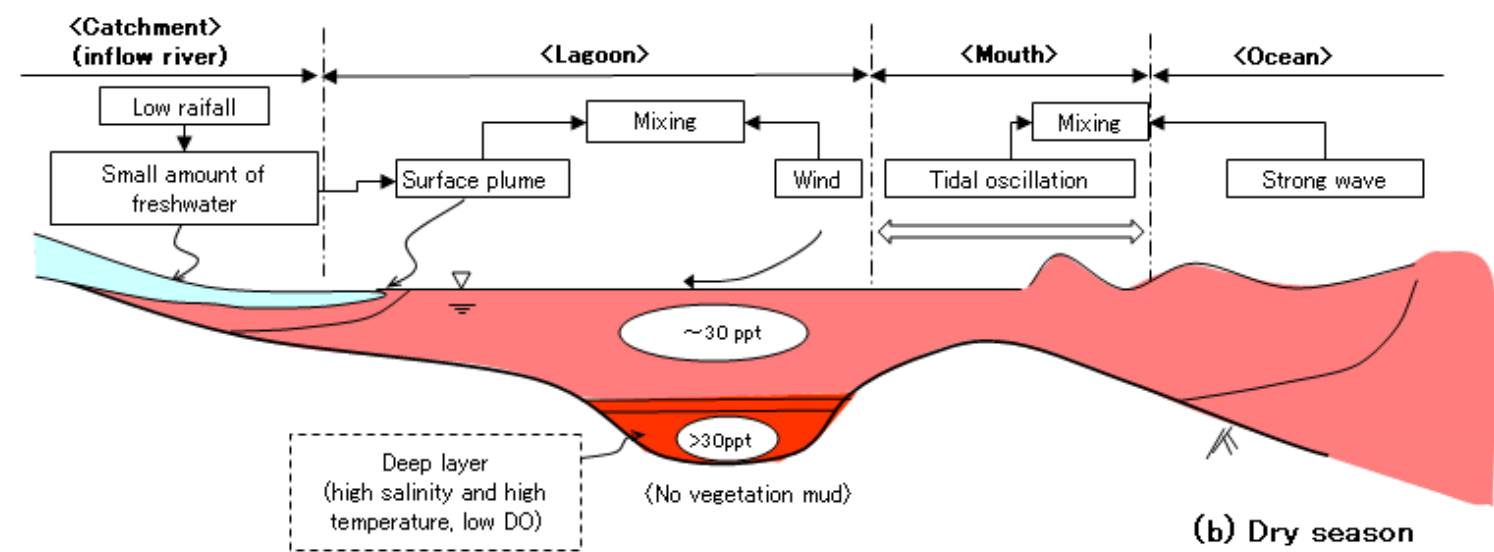

図-6 潟口開口後のコッガラ潟湖における雨季 (a) と乾季 (a) の塩分成層状態の模式図 (小潮下げ潮条件)

の水収支特性については明らかとなっている。

一般的に，潟湖を含む汽水域における塩分の混合形態 には強混合から弱混合の幅があり，それに応じた塩分の 平面・空間分布が汽水域内で形成される，その分布は同 一箇所においても潮汐や降雨量に応じて時間的に変動す る. 本調査において，現在のコッガラ潟湖における時空 間的な塩分の不均一性に加えて，雨季における最深部 (図-3)や乾季の潟湖全域(図-4)において海水レベルの塩分 水塊の存在が確認された。

Silvaらは1981年4月から1年間潟湖内の流軸方向4地点 で実施した現地調查結果から，最も塩分濃度が高い傾向 のある潟口付近における塩分季節変化として，乾季(3月 および8月)に塩分が高く(約18ppt), 雨季(11月)には低下 し0.5pptであったことを報告している9 . こうした塩分上 昇は潟口付近に限られ，流入河川付近の上流地点では乾 季に観測された年間最高塩分は8pptであった これらは表層観測值であり，開口前の塩分成層状況は不 明である。

Priyadarshana $ら^{11}$ は，潟口の開口に伴い1995年に15種確 認された淡水あるいは汽水性の水生植物が，2007年には 3種のみとなったことを報告している．開口前に潟湖全 域に分布してた水生植物の開口後の消失は，ヨシやガマ 等の抽水植物に加えて浮葉・沈水植物の全ての水生植物
タイプで生じた。残存植物の1種であるカワツルモ (Ruppia maritima)は，70pptまでの高塩分でも而性がある ことが報告されている ${ }^{10)}$. 一方，消失した 12 種には，ス

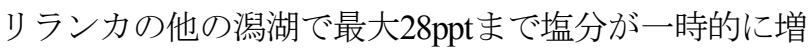
加する箇所でも生育しているイバラモ(Najas marina)も含 まれている ${ }^{11)}$. 本調査で雨季に観測された表層濃度は $15 \mathrm{pp}$ 弱であり，これは開口前の塩分の範囲内であった ${ }^{9}$. ただし同時期の底層では30pptの高塩分底層水の存在が 確認された。潟口から海水性海草の分布域が近年拡大し

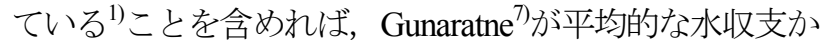
ら推測した現在の塩分である24pptよりも，高い塩分水 塊が季節あるいは場所に応じて生じた結果，一定の耐塩 性のあるイバラモですら消失したと考えられる。すなわ ち，現在のコッガラ潟湖の深部は年間を通じて海水レベ ルの塩分となっていると考えられる，なお，本論文では 流軸に沿った調查結果を用いて植生の消長に関する議論 を行った．植生の開口前後の変化は全域的に生じたこと, 流軸横断方向に比べて長い流軸方向でも潟湖内塩分は平 面的に顕著な差は確認できないことから，限られた本論 文のデータからでもこの議論は可能であると考えられる。 現在生じている底層の高塩分水塊は成層強度も増加さ せ，鉛直混合の抑制および下層水の滞留に繋がる．八ビ タットとしての底層塩分環境の時間変動を評価するため 
には，上述したような生育生物を指標とした間接的な塩 分環境の推測だけでなく, 混合の頻度を水理学的に解析 する必要がある. Gunaratneら ${ }^{4,7}$ は新たな突堤により潟口 部の開口面積および漂砂動態を制御することにより潟湖 の淡・塩水の水収支バランスの状態が開口前に近づく可 能性を指摘している. しかしながら，潟湖の水環境や生 態系保全を工学的に進めてゆくためには，局所的および 時間的な塩分や変動特性についても現状把握と過去の推 定を行った上で, 望ましい将来像について議論する必要 がある.

\section{(2) 今後の課題}

コッガラ潟湖における生態系基盤としての塩分成層特 性について評価する上で，流入河川から潟口部までの各 水域における以下の課題を抽出した．本調査で確認され た特徵的な現象である底層低DO水塊の起源や輸送・動 態については，更なる調査や解析で明らかにする必要が ある.

もう一つの課題が流入河川水量の見積もりである. 本 調查によって, 流入河川が塩分成層化していることが初 めて確認された. Gunaratne ら ${ }^{4}$ はコッガラ潟湖の水文学 的評価において, 流入河川水を淡水とし, 流入水量を表 層流速のみから推測している. 本調査で確認された流入 河川の塩分成層が，潟湖からの遡上水によるものか，あ るいは既に塩化した流域からの流入水として扱うべきな のかについて明らかにする必要がある。

今後のコッガラ潟湖の環境修復においては, 潟湖の水 環境と潟口形状の関係について, 塩分に加えて塩分成層 に着目した研究を実施する必要があると考えられる。

\section{6. 結論}

1）コッガラ潟湖において塩分成層の実態に関する現地 調査を実施した結果，雨季は汽水レベルの緩混合汽 水域であるのに対して, 乾季は海水レベルの塩分の 強混合潟湖であることがわかった。

2）いずれの時季においても，流入河川における塩分成 層に加え潟湖最深部において底部に滞留時間が長い と考えられる高水温高塩分低DO水塊が確認された

3）これらの調查結果に基づいて，潟口開口後における 塩分の空間分布特性を把握し, 現在生じている諸過 程について検討するとともに，既往研究における水 収支特性や動植物相の開口前後の変化に基づいて, 開口による塩分成層への影響を考察した.

4） 今後のコッガラ潟湖における塩分環境の改善に向け た課題について明らかにした。

\section{謝辞}

本研究の実施にあたっては, アジア・アフリカ学術基 盤形成事業(コーディネータ・田中規夫)経費の一部を使 用した. 現地調査の実施に当たっては埼玉大学大学院生
（当時）・安田智史氏の協力を得た．また，3名の查読 者からは有益な意見を頂いた．記して謝意を表します。

\section{参考文献}

1) Priyadarshana, T., Manatunge, J. and Wijeratne, N.: Impacts and consequences of removal of the sand bar at the Koggala lagoon mouth \& Rehabilitation of the lagoon mouth to restore natural formation of the sand bar, Practical Action, Sri Lanka, 2007.

2) Rathnaweera, E: Report on A case study on the impact of the Kapuhenwela causeway on the Rekawa lagoon \& lagoon fishery, Practical Action, Sri Lanka, 2005.

3) Smakhtin, V. U. and Piyankarage, S. C.: Simulating hydrologic reference condition of coastal lagoons affected by irrigation flows in southern Sri Lanka, WETLANDS, 23, pp. 827-834, 2003.

4) Gunaratne, G. L., Tanaka, N., Amarasekara, G. P., Priyadarshana, T. and Manatunge, J.: Impact of rubble mound groyne structural interventions in restoration of Koggala lagoon, Sri Lanka; numerical modelling approach, J Coast. Conserv., 15, pp.113-121, 2011.

5) Furusato, E., Amarasekara, G.P., Priyadarshana, T. and Tanaka, N. : The Current Status of Density Stratification of Koggala Lagoon, Symposium Proceedings of ACEPS (International Symposium on Advances in Civil and Environmental Engineering Practices for Sustainable Development), pp. 176-189, 2012.

6) Amarasekara, G. P., Priyadarshana, T., Manatunge, J., and Tanaka, N.: Impact on Etroplus suratensis (Pisces: Cichlidae) population attributed on human induced hydrological modifications to the Koggala lagoon, Sri Lanka.Proceedings of an International Sympocium of Urban lake monitoring and management. University of Peradeniya, Sri Lanka, pp. 1-9, 2012.

7) Gunaratne, G.L.: Restoration of Koggala Lagoon, Sri Lanka: An investigation of physical processes and morphometric parameters using field data and numerical models and proposing management alternatives, MS thesis, 2010.

8) IWMI (International Water Management Institute), Sri Lanka Wetlands Database, http://dw.iwmi.org/wetland/wetlandsinfooptions.aspx?wetlandname=Koggala\%20Lagoon\&wetland/ (accessed February 10, 2011), 2006.

9) Silva, E.I.L.: Water quality of Sri Lanka, a review on twelve water bodies, Institute of Fundamental Studies, Peradeniya, 1996.

10) Kantrud, H.A.: Wigeongrass (Ruppia maritima L.): A literature Review. US Fish and Wildlife Survey, Fish and Wildlife Research, No. 10. p. 58, 1991.

11) Amarathunga, A.A.D., Sureshkumar, N. Weerasekara, K. A.W.S.., Wickramaarachchi, W.D.N. and Azmy, S. A. M.: Study the effect of salinity and nutrients for the growth of Najas marina and its impact to aquatic biodiversity in Madu Ganda Ramsar wetland in Sri Lanka, Proceedings of the 15th International Forestry and Environment Symposium, pp. 26-27, 2010.

(2012. 9. 30受付) 